\title{
Phebalosin and its Structural Modifications are Active against the Pathogenic Fungal Causing Paracoccidioidomycosis
}

\author{
Fabiana C Missau ${ }^{1,4}$, Susana Johann ${ }^{2 *}$, Nívea Pereira de Sá2, Patrícia S Cisalpino², Carlos A Rosa ${ }^{2}$, Beatriz A Ferreira ${ }^{3}$ and Moacir G \\ Pizzolatti
}

${ }^{1}$ Departamento de Química, Universidade Federal de Santa Catarina, CEP 88040-970, Florianópolis, SC, Brazil

${ }^{2}$ Departamento de Microbiologia, Universidade Federal de Minas Gerais, CEP 31270-901, Belo Horizonte, MG, Brazil

${ }^{3}$ Campus Centro Oeste Dona Lindu, Universidade Federal de São João Del Rei, CEP 35501-296, Divinópolis, MG, Brazil

${ }^{4}$ Campus Itaqui, Universidade Federal do Pampa (UNIPAMPA), CEP 97650-000, Itaqui, RS, Brazil

\begin{abstract}
The phebalosin was isolated from hexane extract of the Polygala paniculata (Polygalaceae). The structural modifications of phebalosin were performed on the epoxy group with different nucleophiles such as $\mathrm{H}_{2} \mathrm{O}$, ethoxy, methoxy, isopropoxy and $n$-butoxy for the corresponding derivatives and with acetic anhydride and acetone to give the diacethyl and cyclic acetal derivatives. The phebalosin and their derivatives were tested against four isolates of the pathogenic fungus Paracoccidioides brasiliensis. In this work phebalosin showed promised antifungal activity against isolates of $P$. brasiliensis with MIC value of 31.2 and $62.5 \mu \mathrm{g} / \mathrm{ml}$. The compound 3 presented the better activity with MIC value of $1.9 \mu \mathrm{g} / \mathrm{ml}$ gainst the isolate $P$. brasiliensis $\mathrm{Pb03}$. Besides, it was used methods of theoretical Chemistry, and chemometrics analysis techniques to perform a SAR study. The compounds activity is due to both types of properties - electronic and structural ones. Overall, these data open new possibilities for the potential use of phebalosin and its structural modifications as antifungal.
\end{abstract}

Keywords: Phebalosin; Paracoccidioidomycosis; antifungal; Polygala paniculata; Molecular modeling; Chemometrics

\section{Introduction}

Coumarins are a vast 1,2-benzopyrone group of natural compounds essentially found in green plants. The substitutions into their basic skeleton 1,2-benzopyrone can occur at any of the six available sites providing them extremely variable structures [1]. Although no longer used as food flavouring, coumarin is present in certain tobaccos and alcoholic beverages and is used in various soup, detergent and cosmetic preparations [2].

Hydroxy derivatives of 4-methyl coumarin are important group of coumarin derivatives showing medicinal as well as other biotechnological applications. For example, 5,7-dihydroxy 4-methyl coumarin and 7,8-dihydroxy 4-methyl coumarins are useful precursors to synthesize respective diacetoxy and hydroxyl-amino derivatives of 4-methyl coumarin, which are known to be good antioxidants having excellent radical scavenging properties [3].

Among the various coumarin derivatives, 7 -substituted coumarins are important groups showing various kinds of bioactivities and also other applications. For example, 7-hydroxy 4-methyl coumarin is used in fluorometric determination of enzymatic activity, as a starting material for the preparation of insecticides and furano coumarins [4]. Due to their inherent photochemical characteristics, reasonable stability, good solubility and relative ease of synthesis, coumarin derivatives have been extensively investigated for electronic and photonic applications [5].

In this present work we screened the coumarin phebalosin and seven phebalosin -derivatives against four clinical isolates of the pathogenic dimorphic fungus Paracoccidioides brasiliensis, the causing agent of Paracoccidioidomycosis (PMC). PCM is the most prevalent systemic endemic mycosis in South America with most reported cases in Brazil [6]. In the absence of drug therapy the disease is usually fatal. The treatment of PCM is usually long, with many patients receiving therapy for one to two years or even more. It appears that the number of drugs active against PCM is scarce [7]. Although azoles and other drugs can arrest the progression of PCM, the fibrosis sequelae persist, probably constituting a source of fungi that could lead to a relapse in the disease following termination of treatment $[8,9]$. The strong toxicity of amphotericin B makes the effective management of this severe disease difficult [10]. For this reason the discovery of new drugs for the treatment of PMC is very important.

\section{Materials and Methods}

\section{Chemistry}

${ }^{1} \mathrm{H}$ and ${ }^{13} \mathrm{C}$ NMR spectra were measured using a Varian $400 \mathrm{MHz}$ spectrometer. A solvent used for NMR measurements was TMS- $\mathrm{CDCl}_{3}$. IR spectra were recorded with a Perkin-Elmer FT 16PC spectrometer ( $\mathrm{KBr}$ pellets). Mass spectra were taken with a Shimadzu QP 5050A at $70 \mathrm{eV}$. TLC: Merck Kieselgel $60 \mathrm{~F}_{254}$, spots were visualized under UV at 254 and $360 \mathrm{~nm}$.

\section{Plant material}

Polygala paniculata was collected in March 2004 on Daniela beach, Florianópolis, Santa Catarina State, Brazil. The specimen was identified by a botanist, Prof. Dr. Olavo Araújo Guimarães, and the voucher specimen number 26027 was deposited at the Herbarium of the Botany Department of Universidade Federal do Paraná (Curitiba, PR, Brazil).

\section{Extraction and isolation}

The dried whole plant (3500 g) was extracted with hexane twice, each for 24 hours at room temperature. The extract was partially concentrated in vacuum with controlled temperature observing the

*Corresponding author: Susana Johann, Departamento de Microbiologia Instituto de Ciências Biológicas, Universidade Federal de Minas Gerais, Av Antônio Carlos, 6627, PO Box 486, 31270-901, Belo Horizonte, MG, Brazil, Tel.: +55 3349 7700; Fax: +55 313295 3115; E-mail: sjohann@icb.ufmg.br

Received June 18, 2014; Accepted July 28, 2014; Published July 30, 2014

Citation: Missau FC, Johann S, de Sá NP, Cisalpino PS, Rosa CA, et al. (2014) Phebalosin and its Structural Modifications are Active against the Pathogenic Fungal Causing Paracoccidioidomycosis. Med chem 4: 581-587. doi:10.4172/21610444.1000197

Copyright: (c) 2014 Missau FC, et al. This is an open-access article distributed under the terms of the Creative Commons Attribution License, which permits unrestricted use, distribution, and reproduction in any medium, provided the original author and source are credited. 
precipitation of a white amorphous solid. The solid was separated from the supernatant solution followed by successive washing with hexane, yielding $2 \mathrm{~g}$ of epoxy coumarin, phebalosin (1).

\section{Structural modification}

Epoxy Ring Hydrolysis of the phebalosin (2): For ring epoxy hydrolysis of phebalosin (1), $100 \mathrm{mg}$ was dissolved in dichloromethane $\left(\mathrm{CH}_{2} \mathrm{Cl}_{2}\right), 10$ mlof distilled water, 1 mlof chloridric acid $(\mathrm{HCl})$ and $5 \mathrm{~g}$ of silica gel (catalyst). The mixture was subjected to magnetic agitation for $72 \mathrm{~h}$ and temperature control $\left(50^{\circ} \mathrm{C}\right)$. After this period, the reaction mixture was extracted with $\mathrm{CH}_{2} \mathrm{Cl}_{2}$, dried with anhydrous sodium sulfate $\left(\mathrm{Na}_{2} \mathrm{SO}_{4}\right)$, filtered and the organic solvent was concentrated. The crude product was purified by chromatography on a flash column (230-400 mesh) with hexane/ethyl acetate $10: 90$ to yield $19 \%$ as a white solid.

MP: $135-136^{\circ} \mathrm{C}$; IR (cm-1): 3384, 2965, 1715, 1603, 1494, 1255.

${ }^{1} \mathrm{H}$ NMR $\left(\mathrm{CDCl}_{3}, 400 \mathrm{MHz}\right): 1.77\left(3 \mathrm{H}, \mathrm{s}, \mathrm{CH}_{3}-5\right)$ ) $3.97(3 \mathrm{H}, \mathrm{s}$, $\left.\mathrm{CH}_{3} \mathrm{O}-\mathrm{C} 7\right), 4.53\left(1 \mathrm{H}, \mathrm{d}, J=8.4 \mathrm{~Hz}, \mathrm{H}-2^{\prime}\right), 4.59\left(1 \mathrm{H}, \mathrm{s}, \mathrm{H}-4^{\prime}\right), 4.65(1 \mathrm{H}, \mathrm{s}$, H-4'), $5.31\left(1 \mathrm{H}, \mathrm{d}, \mathrm{H}-\mathrm{l}^{\prime}\right), 6.26(1 \mathrm{H}, \mathrm{d}, J=9.6 \mathrm{~Hz}, \mathrm{H}-3), 6.88(1 \mathrm{H}, \mathrm{d}, J=$ $8.8 \mathrm{~Hz}, \mathrm{H}-6), 7.40(1 \mathrm{H}, \mathrm{d}, J=8.8 \mathrm{~Hz}, \mathrm{H}-5), 7.63(1 \mathrm{H}, \mathrm{d}, J=9.6 \mathrm{~Hz}, \mathrm{H}-4)$.

Epoxy Ring Ethanolysis of phebalosin (3): The same method of (2) was used for ethanolysis with the substitution of the solvent (water by ethanol). The crude product was purified by chromatography on a flash column (230-400 mesh) with hexane/ethyl acetate 40:60 to yield $26 \%$ as a white solid.

MP: $130-131^{\circ} \mathrm{C}$; IR $\left(\mathrm{cm}^{-1}\right): 3473,2925,1728,1603,1453,1251$.

${ }^{1} \mathrm{H}$ NMR $\left(\mathrm{CDCl}_{3}, 400 \mathrm{MHz}\right): 1.18\left(3 \mathrm{H}, \mathrm{t}, \mathrm{CH}_{3}-\mathrm{CH}_{2} \mathrm{O}-\mathrm{C} 2\right.$ '), 1.69 $\left(3 \mathrm{H}, \mathrm{s}, \mathrm{CH}_{3}-5^{\prime}\right), 3.44\left(2 \mathrm{H}, \mathrm{m}, \mathrm{CH}_{3}-\mathrm{CH}_{2}-\mathrm{O}-\mathrm{C} 2^{\prime}\right), 3.92\left(3 \mathrm{H}, \mathrm{s}, \mathrm{CH}_{3} \mathrm{O}-\mathrm{C} 7\right)$, $4.63\left(1 \mathrm{H}, \mathrm{s}, \mathrm{H}-4^{\prime}\right), 4.69\left(1 \mathrm{H}, \mathrm{s}, \mathrm{H}-4^{\prime}\right), 4.91\left(1 \mathrm{H}, \mathrm{d}, \mathrm{H}-2^{\prime}\right), 5.14(1 \mathrm{H}, \mathrm{d}, J=$ $\left.7.2 \mathrm{~Hz}, \mathrm{H}-1^{\prime}\right), 6.26(1 \mathrm{H}, \mathrm{d}, J=9.6 \mathrm{~Hz}, \mathrm{H}-3), 6.86(1 \mathrm{H}, \mathrm{d}, J=7.0 \mathrm{~Hz}, \mathrm{H}-6)$, $7.40(1 \mathrm{H}, \mathrm{H}-5), 7.87(1 \mathrm{H}, \mathrm{d}, J=9.6 \mathrm{~Hz}, \mathrm{H}-4)$.

\section{Epoxy ring opening of phebalosin with sodium methoxy (4)}

For this reaction, $20 \mathrm{mg}$ of metallic sodium was added to $15 \mathrm{ml}$ of dry methanol. In this solution, $100 \mathrm{mg}$ phebalosin was added and the reaction was terminated after 15 minutes. The reaction medium was acidified with methanol-chloridric acid to $\mathrm{pH} 2-3$. The reaction mixture was extracted with $\left(\mathrm{CH}_{2} \mathrm{Cl}_{2}\right)$, dried with anhydrous sodium sulfate $\left(\mathrm{Na}_{2} \mathrm{SO}_{4}\right)$, filtered and the organic solvent was concentrated in a vacuum desiccator. The crude product was purified by chromatography on a flash column (230-400 mesh) with hexane/ethyl acetate 50:50 to yield $71 \%$ as white solid.

MP: $140-142^{\circ} \mathrm{C}$; IR (cm $\left.{ }^{-1}\right): 3474,2929,1728,1605,1489,1249$.

${ }^{1} \mathrm{H}$ NMR $\left(\mathrm{CDCl}_{3}, 400 \mathrm{MHz}\right): 1.59\left(3 \mathrm{H}, \mathrm{s}, \mathrm{CH}_{3}-5\right), 3.25(3 \mathrm{H}, \mathrm{s}$, $\left.\mathrm{CH}_{3} \mathrm{O}-\mathrm{C} 2{ }^{\prime}\right), 3.93\left(3 \mathrm{H}, \mathrm{s}, \mathrm{CH}_{3} \mathrm{O}-\mathrm{C} 7\right), 4.51\left(1 \mathrm{H}, \mathrm{d}, J=2.0 \mathrm{~Hz}, \mathrm{H}-2^{\prime}\right), 4.65$ $\left(1 \mathrm{H}, \mathrm{s}, \mathrm{H}-1^{\prime}\right), 4.87\left(1 \mathrm{H}, \mathrm{s}, \mathrm{H}-4^{\prime}\right), 5.02\left(1 \mathrm{H}, \mathrm{d}, \mathrm{H}-4^{\prime}\right), 6.24(1 \mathrm{H}, \mathrm{d}, J=9.6$ $\mathrm{Hz}, \mathrm{H}-3), 7.05(1 \mathrm{H}, \mathrm{d}, J=8.8 \mathrm{~Hz}, \mathrm{H}-6), 7.57(1 \mathrm{H}, \mathrm{d}, J=8.8 \mathrm{~Hz}, \mathrm{H}-5)$, $7.87(1 \mathrm{H}, \mathrm{d}, J=9.6 \mathrm{~Hz}, \mathrm{H}-4)$.

\section{Epoxy ring opening of phebalosin with sodium isopropoxy} (5)

For this reaction, the same method of (4) was used with the appropriate nucleophile isoproxy to yield $44 \%$ of the product as white solid.

MP: $101-103^{\circ} \mathrm{C}$, IR $\left(\mathrm{cm}^{-1}\right): 3557,2968,1728,1604,1454,1368$.

${ }^{1} \mathrm{H}$ NMR $\left(\mathrm{CDCl}_{3}, 400 \mathrm{MHz}\right): 1.01\left(3 \mathrm{H}, \mathrm{d}, \mathrm{C2}\right.$ '-OCH- $\left.\left(\mathrm{CH}_{3}\right)_{2}\right), 1.24$ $\left(3 \mathrm{H}, \mathrm{d}, \mathrm{C} 2^{\prime}-\mathrm{CH}-\left(\mathrm{CH}_{3}\right)_{2}\right), 1.70\left(3 \mathrm{H}, \mathrm{s}, \mathrm{CH}_{3}-5^{\prime}\right), 3.54\left(1 \mathrm{H}, \mathrm{m}, \mathrm{C} 2^{\prime}-\mathrm{O}-\mathrm{CH}-\right.$
$\left.\left(\mathrm{CH}_{3}\right)_{2}\right), 3.93\left(3 \mathrm{H}, \mathrm{s}, \mathrm{CH}_{3} \mathrm{O}-\mathrm{C} 7\right), 3.86\left(1 \mathrm{H}, \mathrm{s}, \mathrm{H}-4^{\prime}\right), 3.97$ (1H, s, H-4'), $4.65\left(1 \mathrm{H}, \mathrm{d}, J=8.4 \mathrm{~Hz}, \mathrm{H}-2^{\prime}\right), 4.83\left(1 \mathrm{H}, \mathrm{d}, J=8.4 \mathrm{~Hz}, \mathrm{H}-1^{\prime}\right), 6.26(1 \mathrm{H}, \mathrm{d}$, $J=9.6 \mathrm{~Hz}, \mathrm{H}-3), 6.86(1 \mathrm{H}, \mathrm{d}, J=8.8 \mathrm{~Hz}, \mathrm{H}-6), 7.39(1 \mathrm{H}, \mathrm{d}, J=8.8 \mathrm{~Hz}$, $\mathrm{H}-5), 7.62(1 \mathrm{H}, \mathrm{d}, J=9.6 \mathrm{~Hz}, \mathrm{H}-4)$.

\section{Epoxy ring opening of phebalosin with sodium n-butoxy (6)}

The reaction was carried out using the same procedure as in (4) using t-butoxy a nuccleofilic reagent, to yield $38 \%$ of the product like a white solid.

\section{MP: $97-99^{\circ} \mathrm{C}, \mathrm{IR}\left(\mathrm{cm}^{-1}\right): 3435,2955,1723,1605,1443,1250$.}

${ }^{1} \mathrm{H}$ NMR $\left(\mathrm{CDCl}_{3}, 400 \mathrm{MHz}\right): 0.83\left(3 \mathrm{H}, \mathrm{t}, \mathrm{C2}\right.$ '- $\left.\mathrm{O}\left(\mathrm{CH}_{2}\right)_{3}-\mathrm{CH}_{3}\right), 1.31$ e $1.53\left(2 \mathrm{H}\right.$ each, m, C2'- $\left.\mathrm{OCH}_{2}-\left(\mathrm{CH}_{2}\right)_{2}-\mathrm{CH}_{3}\right), 1.71\left(3 \mathrm{H}, \mathrm{s}, \mathrm{CH}_{3}-5^{\prime}\right), 3.33$ $\left(2 \mathrm{H}, \mathrm{t}, \mathrm{C} 2\right.$ '- $\left.\mathrm{O}-\mathrm{CH}_{2}-\left(\mathrm{CH}_{2}\right)_{2} \mathrm{CH}_{3}\right), 3.93\left(3 \mathrm{H}, \mathrm{s}, \mathrm{CH}_{3} \mathrm{O}-\mathrm{C} 7\right), 4.62(1 \mathrm{H}, \mathrm{s}$, H-4'), 4.69 (1H, s, H-4'), $4.92\left(1 \mathrm{H}, \mathrm{d}, J=8.8 \mathrm{~Hz}, \mathrm{H}-2^{\prime}\right), 5.14(1 \mathrm{H}, \mathrm{d}, J=$ $\left.8.8 \mathrm{~Hz}, \mathrm{H}-1^{\prime}\right), 6.26(1 \mathrm{H}, \mathrm{d}, J=9.2 \mathrm{~Hz}, \mathrm{H}-3), 6.99(1 \mathrm{H}, \mathrm{d}, J=8.8 \mathrm{~Hz}, \mathrm{H}-6)$, $7.45(1 \mathrm{H}, \mathrm{d}, J=8.8 \mathrm{~Hz}, \mathrm{H}-5), 7.67(1 \mathrm{H}, \mathrm{d}, J=9.2 \mathrm{~Hz}, \mathrm{H}-4)$.

\section{Obtaining cyclic acetal of phebalosin with acetone (7)}

The acetalization reaction of phebalosin (1) was performed in dry acetone $(100 \mathrm{mg})$ by dissolution of the $100 \mathrm{mg}$ of phebalosin with addition $1 \mathrm{ml}$ of chloridric acid $(\mathrm{HCl})$ and $5 \mathrm{~g}$ of silica gel (catalyst). The mixture was subjected to magnetic agitation for $72 \mathrm{~h}$ and temperature control $\left(50^{\circ} \mathrm{C}\right)$. After this period, the reaction mixture was extracted with $\left(\mathrm{CH}_{2} \mathrm{Cl}_{2}\right)$, dried with anhydrous sodium sulfate $\left(\mathrm{Na}_{2} \mathrm{SO}_{4}\right)$, filtered and the organic solvent was concentrated. The crude product was purified by chromatography on a flash column (230-400 mesh) with hexane/ethyl acetate $40: 60$ to yield $70 \%$ as white solid.

MP: $111-112^{\circ} \mathrm{C}$; IR $\left(\mathrm{cm}^{-1}\right): 2980,1724,1603,1488,1375,1245$.

${ }^{1} \mathrm{H} \mathrm{NMR}\left(\mathrm{CDCl}_{3}, 400 \mathrm{MHz}\right): 1.54\left(3 \mathrm{H}, \mathrm{s}, \mathrm{CH}_{3}-8\right.$ '), $1.70\left(3 \mathrm{H}, \mathrm{s}, \mathrm{CH}_{3}-\right.$ 7'), $1.74\left(3 \mathrm{H}, \mathrm{s}, \mathrm{CH}_{3}-5^{\prime}\right), 3.93\left(3 \mathrm{H}, \mathrm{s}, \mathrm{CH}_{3} \mathrm{O}-\mathrm{C} 7\right), 4.85$ (1H, s, H-4'), 4.96 $\left(1 \mathrm{H}, \mathrm{s}, \mathrm{H}-4^{\prime}\right), 5.02\left(1 \mathrm{H}, \mathrm{d}, J=9.6 \mathrm{~Hz}, \mathrm{H}-2^{\prime}\right), 5.57(1 \mathrm{H}, \mathrm{d}, J=9.6 \mathrm{~Hz}$, H-1'), $6.26(1 \mathrm{H}, \mathrm{d}, J=8.8 \mathrm{~Hz}, \mathrm{H}-3), 6.87(1 \mathrm{H}, \mathrm{d}, J=8.0 \mathrm{~Hz}, \mathrm{H}-6), 7.41$ $(1 \mathrm{H}, \mathrm{d}, J=8.0 \mathrm{~Hz}, \mathrm{H}-5), 7.61(1 \mathrm{H}, \mathrm{d}, J=8.8 \mathrm{~Hz}, \mathrm{H}-4)$.

\section{Acetilation of phebalosin (8)}

The acetylation of phebalosin (1) (100 mg) with acetic anhydride $(2 \mathrm{ml})$, acetic acid $(1 \mathrm{ml})$, catalyzed by 4 -(dimethylamino)pyridine (DMAP) was dissolved in ethyl acetate $(3 \mathrm{ml})$. The mixture was submitted to magnetic agitation for $72 \mathrm{~h}$. After the reaction the solvent is evaporated in vacuum desiccator. The crude product was purified by chromatography on a flash column (230-400 mesh) with hexane/ethyl acetate $50: 50$ to yield $65 \%$ as white solid.

\section{MP: $120-121^{\circ} \mathrm{C}$; IR $\left(\mathrm{cm}^{-1}\right)$ : 2943, 1741, 1606, 1494, 1244.}

${ }^{1} \mathrm{H} \mathrm{NMR}\left(\mathrm{CDCl}_{3}, 400 \mathrm{MHz}\right): 1.48\left(3 \mathrm{H}, \mathrm{s}, \mathrm{CH}_{3}-5\right.$ '), $1.87\left(3 \mathrm{H}, \mathrm{s}, \mathrm{CH}_{3}-\right.$ $\mathrm{CO}), 1.92\left(3 \mathrm{H}, \mathrm{s}, \mathrm{CH}_{3}-\mathrm{CO}\right), 3.82\left(3 \mathrm{H}, \mathrm{s}, \mathrm{CH}_{3} \mathrm{O}-\mathrm{C} 7\right), 4.57\left(1 \mathrm{H}, \mathrm{s}, \mathrm{H}-4^{3}\right)$, $4.76\left(1 \mathrm{H}, \mathrm{s}, \mathrm{H}-4^{\prime}\right), 5.98\left(1 \mathrm{H}, \mathrm{d}, J=12.0 \mathrm{~Hz}, \mathrm{H}-2^{\prime}\right), 6.08(1 \mathrm{H}, \mathrm{d}, J=12.0$ $\left.\mathrm{Hz}, \mathrm{H}-1^{\prime}\right), 6.57(1 \mathrm{H}, \mathrm{d}, J=8.0 \mathrm{~Hz}, \mathrm{H}-3), 6.76(1 \mathrm{H}, \mathrm{d}, J=8.0 \mathrm{~Hz}, \mathrm{H}-6)$, $7.33(1 \mathrm{H}, \mathrm{d}, J=8.0 \mathrm{~Hz}, \mathrm{H}-5), 7.54(1 \mathrm{H}, \mathrm{d}, J=8.0 \mathrm{~Hz}, \mathrm{H}-4)$.

\section{Paracoccidioides brasiliensis strains}

Four clinical isolates of $P$. brasiliensis, $\mathrm{Pb} 18$ (from the fungal collection of the Faculty of Medicine of the Universidade de São Paulo, São Paulo, SP, Brazil), Pb03 (clinical isolates from chronic PCM, São Paulo, Brazil- MHH Forjaz / TIE Svidzinski), Pb01 (ATCC- MYA826) and Pb339 (ATCC 32069), were used in the biological assays.

\section{Inoculum preparation}

The strains were maintained by weekly passage in solid Yeast- 
Peptone-Dextrose medium, at $37^{\circ} \mathrm{C}$ and were used after 7-10 days of fungus growth. Yeast cells in the exponential phase were collected aseptically with a platinum loop and re-suspended in a tube containing $5 \mathrm{ml}$ of sterile saline. If large aggregates existed, they were allowed to settle for several minutes, and the supernatants were collected. The suspensions were then diluted in synthetic RPMI medium (Sigma, St. Louis, MO, USA) with L-glutamine buffered to $\mathrm{pH} 7.0$ with 0.165 morpholine propanesulfonic acid (MOPS, Sigma), and prepared according to the CLSI document $\mathrm{M} 27-\mathrm{A}_{2}$ [11] to obtain a final inoculum size suitable for the strains [12]. After homogenization by vortexing, transmittance was measured at $520 \mathrm{~nm}$ and adjusted to 69 to $70 \%[13]$.

\section{Susceptibility test}

The compounds were dissolved in dimethylsulfoxide (DMSO). Serial dilutions were then performed, using RPMI as a diluent, maintaining a constant volume of $1 \mathrm{ml}$ per tube. The extracts were tested at eight different concentrations that ranged from 500-1.9 $\mu \mathrm{g}$ / $\mathrm{ml}$ Volumes of $100 \mu \mathrm{l}$ of each dilution were distributed in sterile flatbottom 96-well microplates (Difco Laboratories, Detroit, MI, USA).

Susceptibility was determined by the broth microdilution method. Broth microdilution testing was performed in accordance with the guidelines in the CLSI M27-A document [11] and Nakai et al. [12] RPMI medium was used without compounds or solvents as a control for growth and sterility. Solvent DMSO at the same volumes used in the assay was used as control for toxicity. Amphotericin B (Sigma, St Louis, USA) ( 25 to $0.03 \mu \mathrm{g} / \mathrm{ml}$ and ( 25 to $0.03 \mu \mathrm{g} / \mathrm{ml}$ in DMSO was included as positive antifungal control with the stock solutions prepared in DMSO and water, respectively. After inoculation of fungal strains the plates were incubated at $37^{\circ} \mathrm{C}$ for 14 days. The tests were performed in triplicate in at last two independent experiments. The endpoints were determined visually by comparison with the drug-free growth control well. MICs were expressed in $\mu \mathrm{g} / \mathrm{ml}$ and defined as the lowest compound concentration for which the well was optically clear. All assays were performed in triplicate and repeated at least once.

\section{Theoretical Chemistry methodology and chemometrics}

Structural and electronic properties were obtained from classical mechanics [14] calculations (AMBER force field, at $298 \mathrm{~K}$, in a vacuum) implemented in HYPERCHEM 7.5 molecular modelling program [15] and $\mathrm{HF} / 6-31 \mathrm{G}^{* *}$ electronic structure calculations ( $a b$ initio method of Quantum Chemistry [16], $298 \mathrm{~K}$, in a vacuum), implemented in GAUSSIAN program [17]. The obtained data were compared and correlated with antifungal activity by using chemometrics analysis [18]: Hierarchical Clustering Analysis (HCA), Partial Least Squares (PLS) and Principal Component Analysis (PCA) methods by using MINITAB $15^{\circ}$ program [19].

\section{Results}

Whole $P$. paniculata plants were extracted with hexane to afford the coumarin phebalosin as a white amorphous solid, m.p. $124^{\circ} \mathrm{C}$ (Lit. $121-123^{\circ} \mathrm{C}$ ); Rf=0.39 (eluent $60: 40$ hexane/ethyl acetate) and was identified by spectroscopic analysis and comparison with literature data [20]. A study of the reactivity of phebalosin (1) was planned, preparing a series of derivatives involving the opening epoxide ring by nucleophilic substitution reactions using different reagents, acetylation and formation of the cyclic acetal as shown in Figure 1.

The phebalosin (1) was treated with water and silica gel under<smiles>C=C(C)C(OCC)C(O)c1c(OC)ccc2ccc(=O)oc12</smiles>

(3)<smiles>C=C(C)C(O)C(O)c1c(OC)ccc2ccc(=O)oc12</smiles>

(2)<smiles>C=C(C)C1OC(C)(C)OC1c1c(OC)ccc2ccc(=O)oc12</smiles>

(7)<smiles>C=C(C)C(OC(C)C)C(O)c1c(OC)ccc2ccc(=O)oc12</smiles>

(5)<smiles>C=C(C)C(O)C(O)c1c(OC)ccc2ccc(=O)oc12</smiles>

(4)<smiles>C=C(C)C1OC1C1C(OC)=CC=C2C=CC(=O)OC21</smiles>

(1)

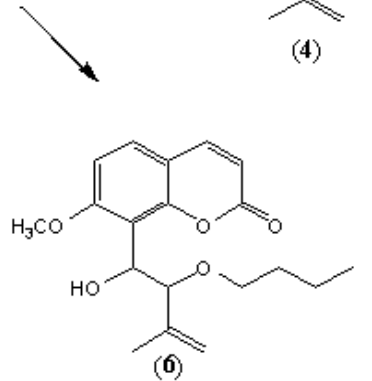

Figure 1: Structural modifications of phebalosin (1), reaction of phebalosin with $\mathrm{H}_{2} \mathrm{O}$ (2), ethanol (3), methoxy sodium (4), isopropoxy sodium (5) and $n$-butoxy sodium (6), acetone (7), and acetic anhydride (8). 
agitation being partially converted to a dihydroxy derivative $3(19 \%)$ which presented itself in the form of a white solid with MP 135$136^{\circ} \mathrm{C}$ (Lit. $135-136^{\circ} \mathrm{C}$; [18] $\mathrm{Rf}=0.38$ (eluent ethyl acetate $100 \%$ ). The spectrum in region IR in $\mathrm{KBr}$ pellets showed the appearance of intense hydroxyl absorption at $v 3384 \mathrm{~cm}^{-1}$, showing the opening of the epoxide ring, while it maintained the other absorption characteristics of coumarin. The ${ }^{1} \mathrm{H}$ NMR spectrum of the reaction product kept the absorption characteristics of the coumarin nucleus: Halfway prenyl, the displacement of hydrogen atoms $\mathrm{H}^{-1}$ ' and $\mathrm{H}-2$ ' of $3.92 \mathrm{ppm}$ and $3.99 \mathrm{ppm}$ (epoxy) to $5.31 \mathrm{ppm}(1 \mathrm{H}, \mathrm{d})$ and $4.53 \mathrm{ppm}(1 \mathrm{H}, \mathrm{d}, J=8.4$ $\mathrm{Hz}$ ) respectively was observed due to the formation of a diol derivative.

In the treatment with ethanol and silica gel under agitation, phebalosin was converted to a 1'-hydroxy-2'-ethoxy derivative (26\%) which was presented in the form of white solid, with MP $130-131^{\circ} \mathrm{C}$, with $\mathrm{Rf}=0.32$ (eluent hexane/ethyl acetate 50:50). The spectrum in region IR in $\mathrm{KBr}$ pellets showed the appearance of intense hydroxyl absorption at $v 3473 \mathrm{~cm}^{-1}$, showing the opening of the epoxide ring, and the other absorption characteristics of coumarin. The ${ }^{1} \mathrm{H}$ NMR spectrum of the reaction product kept the absorption characteristics of the coumarin nucleus. Halfway prenyl, we observed the displacement of hydrogen atoms H-1' and H-2' of 3.92 and 3.99 ppm (epoxide) to $5.14 \mathrm{ppm}(1 \mathrm{H}, \mathrm{d}, J=7.20 \mathrm{~Hz})$ and $4.91 \mathrm{ppm}(1 \mathrm{H}, \mathrm{d})$ respectively, due to the formation of the ethoxy derivative; furthermore was observed an additional spin system to ethoxy group at $1.18 \mathrm{ppm}(3 \mathrm{H}, \mathrm{t})$ and 3.44 $\operatorname{ppm}(2 \mathrm{H}, \mathrm{m})$.

The phebalosin react quickly with sodium methoxy to give 1'-hydroxy-2'-methoxy derivative 4 (71\%) as a white solid, with MP $140-142^{\circ} \mathrm{C}$, and $\mathrm{Rf}=0.24$ (eluent hexane/ethyl acetate 50:50). The spectrum in the IR region in $\mathrm{KBr}$ pellets showed the appearance of intense hydroxyl absorption at $v 3476 \mathrm{~cm}^{-1}$, showing the opening of the epoxide ring, keeping the other absorption characteristics of coumarin. The ${ }^{1} \mathrm{H}$ NMR spectrum of the reaction product kept the absorption characteristics of the coumarin nucleus. Halfway prenyl, the displacement of hydrogen atoms $\mathrm{H}-1^{\prime}$ and $\mathrm{H}-2$ ' of 3.92 and 3.99 ppm (epoxide) to $4.65 \mathrm{ppm}(1 \mathrm{H}, \mathrm{d}, J=2.0 \mathrm{~Hz})$ and $4.51 \mathrm{ppm}(1 \mathrm{H}$, $\mathrm{d}, J=2.0 \mathrm{~Hz}$ ) respectively was observed, due to the formation of the methoxy derivative. Additionally, the ${ }^{1} \mathrm{H}$ NMR spectrum recorded the appearance of a absorption at $3.25 \mathrm{ppm}(3 \mathrm{H}, \mathrm{s})$ to additional methoxy group.

The reaction with sodium isopropoxy afforded 1'-hydroxy-2'isopropoxy derivative 5 (44\%) presented in the form of a white solid, with $\mathrm{MP} 101-103^{\circ} \mathrm{C}$, and $\mathrm{Rf}=0.48$ (eluent hexane/ethyl acetate $50: 50$ ). The spectrum in the IR region in $\mathrm{KBr}$ pellets showed the appearance of hydroxyl absorption at $v 3557 \mathrm{~cm}^{-1}$, showing the opening of the epoxide ring, keeping other absorption characteristics of coumarin. The ${ }^{1} \mathrm{H}$ NMR spectrum of the reaction product kept the absorption characteristics of the coumarin nucleus. Halfway prenyl, we observed the displacement of hydrogen atoms $\mathrm{H}-1^{\prime}$ and $\mathrm{H}-2$ ' of 3.92 and 3.99 ppm (epoxide) to $4.83 \mathrm{ppm}(1 \mathrm{H}, \mathrm{d}, J=8.4 \mathrm{~Hz})$ and $4.65 \mathrm{ppm}(1 \mathrm{H}, \mathrm{d}, J=$ $8.4 \mathrm{~Hz}$ ) respectively, due to the opening of the ring and the appearance an additional spin system at $1.01 \mathrm{ppm}(3 \mathrm{H}, \mathrm{d}), 1.24 \mathrm{ppm}(3 \mathrm{H}, \mathrm{d})$ and $3.54 \mathrm{ppm}(1 \mathrm{H}, \mathrm{m})$ to isopropoxy group inserted.

The reaction with sodium n-buthoxy gives the 1'-hydroxy-2'-nbuthoxy derivative $6(38 \%)$. The compound was presented in the form of yellow solid, with $\mathrm{MP} 97-99^{\circ} \mathrm{C}$, and $\mathrm{Rf}=0.52$ (eluent hexane/ethyl acetate 50:50). The spectrum in the IR region in $\mathrm{KBr}$ pellets showed the appearance of hydroxyl absorption at $v 3435 \mathrm{~cm}^{-1}$, showing the opening of the epoxide ring, keeping other absorption characteristics of coumarin. The ${ }^{1} \mathrm{H}$ NMR spectrum of the reaction product kept the absorption characteristics of the coumarin nucleus. Halfway prenyl, the displacement of hydrogen atoms H-1' and H-2' of 3.92 and 3.99 ppm (epoxide) to $5.14 \mathrm{ppm}(1 \mathrm{H}, \mathrm{d}, J=8.8 \mathrm{~Hz})$ and $4.92 \mathrm{ppm}(1 \mathrm{H}, \mathrm{d}, J=$ $8.8 \mathrm{~Hz}$ ) was observed respectively. We also observed the appearance of the signals $0.82 \mathrm{ppm}(3 \mathrm{H}, \mathrm{t}), 1.31 \mathrm{ppm}(2 \mathrm{H}, \mathrm{m}), 1.53 \mathrm{ppm}(2 \mathrm{H}, \mathrm{m})$ and $3.33 \mathrm{ppm}(2 \mathrm{H}, \mathrm{t})$ of the n-butoxy group inserted.

The treatment of phebalosin with acetone and silica gel under agitation lead to formation of the respective cyclic derivative (20\%) as a colorless crystal, with MP $111-112^{\circ} \mathrm{C}$, with $\mathrm{Rf}=0.58$ (eluent hexane/ ethyl acetate 50:50). The spectrum in the IR region in $\mathrm{KBr}$ pellets showed the appearance of intense hydroxyl absorption at $v 2980 \mathrm{~cm}^{-1}$, showing the opening of the epoxide ring, while it maintained the other absorption characteristics of coumarin. The NMR spectrum of the reaction product kept the absorption characteristics of the coumarin nucleus. Halfway prenyl, a pair of doublet absorbing at $\delta_{\mathrm{H} 1}, 5.57$ and $\delta_{\mathrm{H} 2}, 5.02 \mathrm{ppm}(1 \mathrm{H}$ each, $\mathrm{d}, J=9.60 \mathrm{~Hz})$ was displaced in relation to epoxy moiety. The singlets that absorb at $1.70 \mathrm{ppm}$ and $1.74 \mathrm{ppm}$, with integration for three hydrogen atoms each, were assigned to the two methyl H-8' and H-7' of the acetal group.

Under acetylation with acetic acid and acetic anhydride under agitation, the phebalosin was partially converted to a diacetyl derivative 8 (65\%) which presented itself in the form of solid white, with MP 120 $121^{\circ} \mathrm{C}$, with $\mathrm{Rf}=0.40$ (eluent hexane/ethyl acetate $50: 50$ ). The spectrum in the IR region in $\mathrm{KBr}$ pellets showed no absorption of hydroxyl and retained all other characteristic absorptions of coumarin. The ${ }^{1} \mathrm{H} N M R$ spectrum of the reaction product kept the absorption characteristics of the coumarin nucleus. Halfway prenyl, we observed the displacement of hydrogen atoms $\mathrm{H}-1^{\prime}$ and $\mathrm{H}-2$ ' of 3.92 and $3.99 \mathrm{ppm}$ (epoxide) to 6.08 $\operatorname{ppm}(1 \mathrm{H}, \mathrm{d}, J=12.0 \mathrm{~Hz})$ and $5.99 \mathrm{ppm}(1 \mathrm{H}, \mathrm{d}, J=12.0)$ respectively, due to the formation of acetyl derivative. The acetylation is confirmed by the presence of signals $1.87 \mathrm{ppm}(3 \mathrm{H}, \mathrm{s})$ and $1.92 \mathrm{ppm}(3 \mathrm{H}, \mathrm{s})$ relative to the acetyl groups.

\section{Antifungal activity}

In this work, the phebalosin was active against all isolates of $P$. brasiliensis tested (Table 1). The MIC values ranged from 31.2 to 500 $\mu \mathrm{g} / \mathrm{ml}$ In relation to the phebalosin-derivative compounds, an increase of antifungal activity was observed for compounds 3, 5 and 6 against isolate $\mathrm{Pb} 03$ of $P$. brasiliensis. However, $\mathrm{Pb} 18$ did not present significant susceptibility against the compounds 7,8 and 4 . Isolate $\mathrm{Pb} 03$ was more susceptive to drugs tested but not for trimethoprim-sulfamethoxazole $(300 \mu \mathrm{g} / \mathrm{ml})$ in the tested conditions.

\section{Molecular modelling and chemometrics}

The coumarin phebalosin compound and its seven phebalosin derivatives had the optimization of their geometries realized through Classical Mechanics (AMBER force field, vacuum, $298 \mathrm{~K}$ ) aimed at obtaining the structure with a minimum of energy. Then used the PM3 level of theory [15] (semiempirical quantum mechanics) at 298 $\mathrm{K}$, vacuum, in order to determine the physico-chemical properties of interest (descriptors). All protocol for obtaining descriptors was held in the programmes HyperChem Professional 75 and GAUSSIAN 09. In this work, the following descriptors were determined through the protocol described in the previous section (Table 2): enthalpy of formation $\left(\Delta \mathrm{H}_{\mathrm{f}}^{\circ}\right)$, variation of energy between the frontier orbitals (the highest occupied energy - HOMO and lowest unoccupied energy LUMO), $\Delta \mathrm{E}_{\text {номо-LUмо, }}$ lipophilicity parameter $(\log \mathrm{P})$, dipole moment $(\mu)$, polarizability, molecular volume, solvent accessible area $(\mathrm{SA})$ and system energy (Hartree Fock energy, at $6-31 G^{* *}$ level of theory). The values of activity were converted into $\log (1 / a)$ from each antifungal analysis, where $\mathrm{a}=$ experimental activity.

Initially it was applied a hierarchical method agglomerative (HCA) 


\begin{tabular}{|c|c|c|c|c|c|c|c|c|}
\hline \multirow{2}{*}{ Compound } & \multicolumn{2}{|c|}{$\mathrm{Pb} 18$} & \multicolumn{2}{|c|}{$\mathrm{Pb} 03$} & \multicolumn{2}{|c|}{$\mathrm{Pb} 01$} & \multicolumn{2}{|c|}{ Pb339 } \\
\hline & $\mu \mathrm{g} / \mathrm{mL}$ & $\mu \mathrm{mol} / \mathrm{L}$ & $\mu \mathrm{g} / \mathrm{mL}$ & $\mu \mathrm{mol} / \mathrm{L}$ & $\mu \mathrm{g} / \mathrm{mL}$ & $\mu \mathrm{mol} / \mathrm{L}$ & $\mu \mathrm{g} / \mathrm{mL}$ & $\mu \mathrm{mol} / \mathrm{L}$ \\
\hline 1 & 32.2 & 120 & 31.2 & 120.0 & - & - & - & - \\
\hline 2 & 62.5 & 248.0 & 31.2 & 127.0 & 125.0 & 504.0 & 250.0 & 120.0 \\
\hline 3 & 62.5 & 214.0 & 1.9 & 6.5 & 125.0 & 428.0 & 125.0 & 428.0 \\
\hline 4 & 500 & 1582.0 & 250.0 & 791.0 & - & - & - & - \\
\hline 5 & $\geq 500$ & $\geq 2049.0$ & 31.2 & 127.8 & - & - & - & - \\
\hline 6 & 500 & 1724.0 & 62.5 & 215.5 & - & - & - & - \\
\hline 7 & 62.5 & 196.5 & 7.8 & 24.5 & 125.0 & 393.0 & 125.0 & 393.0 \\
\hline 8 & 31.2 & 93.9 & 15.6 & 46.9 & 125.0 & 376.0 & 62.5 & 188.2 \\
\hline Amphotericin B & 0.06 & 0.06 & 0.02 & 0.02 & 0.06 & 0.06 & 0.06 & 0.06 \\
\hline Trimethoprim/ sulfamethoxazole & 300 & $987.10 / 172.20$ & 300.0 & $987.10 / 172.20$ & 75.0 & $246.4 / 43.0$ & 75.0 & $246.4 / 43.0$ \\
\hline
\end{tabular}

-: not determined;

Table 1: Antifungal activity of phebalosin and compounds derivatives against clinical isolates of Paracoccidioides.

\begin{tabular}{|c|c|c|c|c|c|c|c|c|c|c|c|}
\hline compound & $\log \left(1 / c_{P b 18}\right)$ & $\log \left(1 / c_{P b 03}\right)$ & $\log \left(1 / c_{P b 01}\right)$ & $\log \left(1 / c_{\text {Рbззя }}\right)$ & $\Delta \mathrm{E}_{\text {номо-цuмо }}+/ \mathrm{eV}$ & $\mu / D$ & $\log P$ & polarizability $\stackrel{\mathrm{o}}{\mathrm{A}}^{3}$ & volume/ $\stackrel{\mathrm{A}}{3}^{3}$ & $\mathrm{SA} / \mathrm{o}^{2}$ & $\begin{array}{c}\Delta \mathrm{Hf} \\
\mathrm{kcal} / \mathrm{mol}\end{array}$ \\
\hline 1 & -1.494 & -1.494 & -1.796 & -1.796 & 8.64 & 4.27 & 2.17 & 27.01 & 749.17 & 378.21 & -53.39 \\
\hline 2 & -1.796 & -1.494 & -2.097 & -2.398 & 8.47 & 8.59 & 1.45 & 28.33 & 788.71 & 389.21 & -135.69 \\
\hline 3 & -1.796 & -0.279 & -2.097 & -2.097 & 8.45 & 7.19 & 2.17 & 32.09 & 868.97 & 427.31 & -135.74 \\
\hline 4 & -2.699 & -1.796 & - & - & 8.30 & 7.42 & 1.73 & 30.17 & 844.10 & 422.51 & -129.55 \\
\hline 5 & -1.796 & -0.892 & -2.097 & -2.097 & 8.42 & 7.06 & 2.58 & 33.93 & 901.74 & 447.00 & -135.16 \\
\hline 6 & -1.494 & -1.193 & -2.097 & -1.796 & 8.30 & 7.47 & 2.93 & 35.67 & 1006.37 & 532.34 & -143.46 \\
\hline 7 & -2.699 & -2.398 & - & - & 8.39 & 6.99 & 2.75 & 33.06 & 897.09 & 447.40 & -130.97 \\
\hline 8 & -2.699 & -1.494 & - & - & 8.33 & 9.40 & 1.59 & 34.57 & 987.55 & 477.63 & -201.72 \\
\hline
\end{tabular}

* dipole moment

** Surface Area

Table 2: Antifungal activity $(\mu \mathrm{g} / \mathrm{ml})$ of phebalosin and their compounds derivatives against clinical isolates of Paracoccidioides brasiliensis and descriptors obtained from $\mathrm{HF} / 6-31 \mathrm{G}^{* *}$ electronic structure calculations (ab initio method of Quantum Chemistry, $298 \mathrm{~K}$, in a vacuum).

with all submissions, each forming its own grouping and by similarity, the final grouping of the clusters (also called final partition) which must, as expected, identify groups whose comments or variables have characteristics in common was determined. PCA and PLS techniques were performed in order to separate the compound as function of their antifungal activities.

Despite a few numbers of compounds and a low range of activity values observed, a chemometric analysis was performed: in a general sense, it seems that polarizability is the most important descriptor for antifungal activity against $\mathrm{Pb} 03, \mathrm{~Pb} 339, \mathrm{~Pb} 18$ and $\mathrm{Pb} 01$, respectively.

The results from PCA technique are showed in Figures 2-5. For $\mathrm{Pb} 339$ (Figure 2) the second PCA component (PC2) was responsible for compounds separation as function for antifungal activity (Cumulative eigenvalues: $75.8 \%, 97.5 \%)$ : $\log \mathrm{P}$

$\mathrm{PC} 1=0.378 \log \left(1 / \mathrm{c}_{\mathrm{Pb} 339}\right)+0.508$ polarizability $+0.537 \mathrm{SA}+0.558$

Minimal values of PC2 are corresponding to the best antifungal activities that mean: lower polarizability and SA values and higher lipophilicity character.

The first PCA component (PC1) separated the compounds (activity) because of two properties, the enthalpy of formation $\left(\Delta \mathrm{H}_{\mathrm{f}}^{\circ}\right)$ and the variation of energy between the frontier orbitals $\left(\Delta \mathrm{E}_{\text {номо-Luмо }}\right)$ for $\mathrm{Pb} 01$ (Figure 3). Higher values of these properties lead to more effective compounds against $\mathrm{Pb} 01$ (Cumulative eigenvalues: 93.9\%; $100.0 \%)$ :

$$
\begin{aligned}
& \mathrm{PC} 1=0.583 \log \left(1 / \mathrm{c}_{\mathrm{Pb01}}\right)+0.591 \Delta \mathrm{H}_{\mathrm{f}}{ }^{\circ}+0.558 \Delta \mathrm{E}_{\text {Hомо-LUмо; }} \\
& \mathrm{PC} 2=-0.490 \log \left(1 / \mathrm{c}_{\mathrm{Pb} 01}\right)+-0.292 \Delta \mathrm{H}_{\mathrm{f}}^{\mathrm{o}}+0.821 \Delta \mathrm{E}_{\text {Hомо-LUмо; }}
\end{aligned}
$$

For $\mathrm{Pb} 18$ the results are not conclusive (Figure 4), but they pointed to three descriptors: volume, surface area (SA) and polarizability (Cumulative eigenvalues 73.8\%; 98.0\%):

$\mathrm{PC} 1=-0.152 \log \left(1 / \mathrm{c}_{\mathrm{pb} 18}\right)+0.579$ volume +0.570 polarizability + $0.563 \mathrm{SA}$;

$\mathrm{PC} 2=0.981 \log \left(1 / \mathrm{c}_{\mathrm{Pb} 18}\right)+0.022$ volume +0.056 polarizability + 0.185 SA.

The PC2 component is responsible for the compounds separation. When those three values increases, the activity increases, either.

Finally, for the $\mathrm{Pb} 03$ fungus, whose compounds revealed the best activities, the second component (PC2) showed a good separation as function of activity (Figure 5):

The properties which describe adequately the antifungal activity are polarizability, volume and the variation of energy between the frontier orbitals $\left(\Delta \mathrm{E}_{\text {номо-LUмо }}\right)$. Cumulative eigenvalues $66.4 \%$; $93.0 \%$ :

$\mathrm{PC} 1=0.040 \log \left(1 / \mathrm{c}_{\mathrm{Pb} 03}\right)-0.538 \Delta \mathrm{E}_{\text {номо-LUмо }}+0.590$ polarizability +0.600 volume;

$\mathrm{PC} 2=0.959 \log \left(1 / \mathrm{c}_{\mathrm{Pb} 03}\right)+0.252 \Delta \mathrm{E}_{\text {номо-LUмо }}+0.122$ polarizability +0.042 volume

In this case, the antifungal activity should be increased by increasing the values of the cited properties.

\section{Discussion}

Currently, there are few works on the search for new drugs against $P$. brasiliensis. San-Blas et al. [21] was one of the prime works with a natural product against this fungus. Recently, Thomaz et al. [22] 

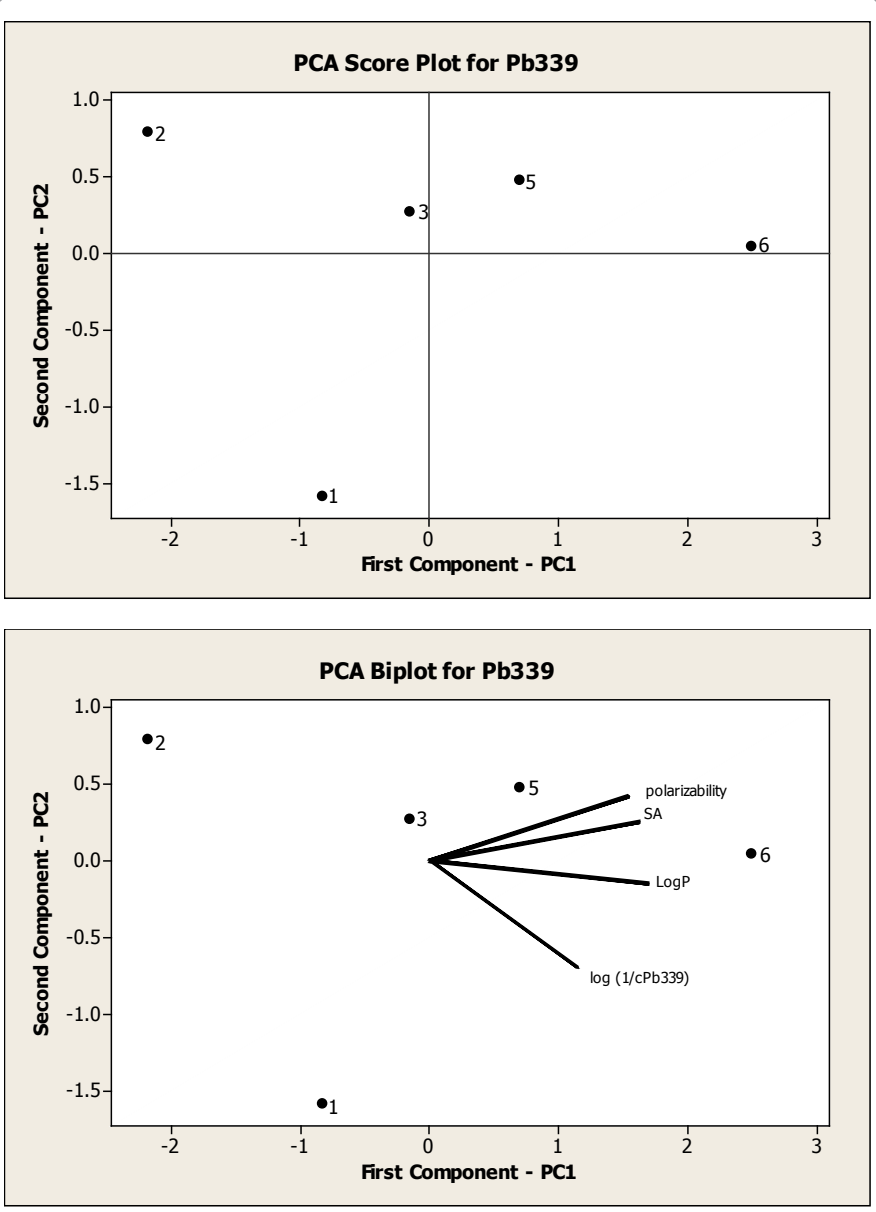

Figure 2: PCA technique showing the compounds separation as function of antifungal activity (Score plot) and the mainly descriptors (Biplot) for Pb339 fungus.

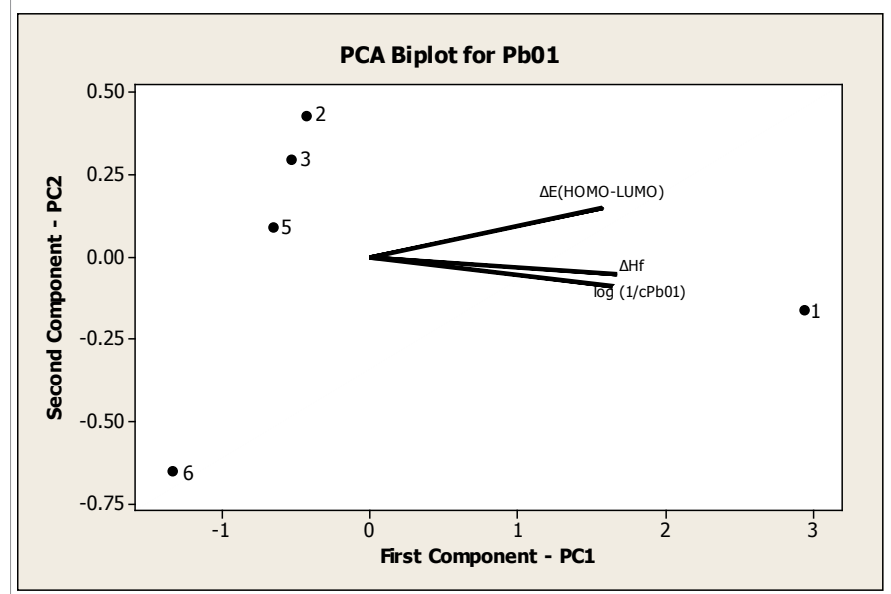

Figure 3: PCA technique showing the compounds separation as function of antifungal activity (Score plot) and the mainly descriptors (Biplot) for Pb01 fungus.

showed that alone from garlic therapy was effective in Balb/c mice infected intra tracheally with the virulent isolate P. brasiliensis $\mathrm{Pb} 18$. Pelegrini et al. [23] have tested peptides from Passiflora edulis against this fungus, but they did not find any effective activity. Marques et al. [24] studied a peptide vaccine with P10, derived from gp43 (major diagnostic antigen), as an adjuvant to chemotherapy, which reduced treatment time, and prevented relapsing disease. In another work, Martins et al. [25], studied the antifungal activity of curcumin, against 23 fungal strains and observed that $P$. brasiliensis were the most susceptive to curcumin. In present work, the phebalosin was active against all isolates of $P$. brasiliensis tested. Due to the great relationship between the coumarins and the biological activities mentioned above, a series of modifications were made to the majority (phebalosin) of Polygala paniculata for the evaluation of a possible improvement in antifungal activity displayed by these compounds. The compound of reaction of phebalosin with ethanol (3) presented strong activity against isolate $\mathrm{Pb} 03$ of $P$. brasiliensis with a MIC values of the 1.9 $\mu \mathrm{g} / \mathrm{ml}(6.5 \mu \mathrm{mol} / \mathrm{L})$, sixteen times more active than phebalosine. The isopropoxy (5) and n-butoxy (6) derivatives were respectively four times and twice more active than phebalosine against $\mathrm{Pb03}$ (Table 1). These experimental results suggest important hydrophobic and steric interaction simultaneously with alkyl groups in the moiety isoprenyl of the phebalosin. This result indicates an activity intermediate to the two drugs used in the treatment of PCM, and the most used in Brazil by the National Health Care System (SUS) is trimethoprim-sulfamethoxazole [25]. Other authors also tested the antifungal activity of amphotericin $\mathrm{B}$ and trimethoprim-sulfamethoxazole against several isolates of

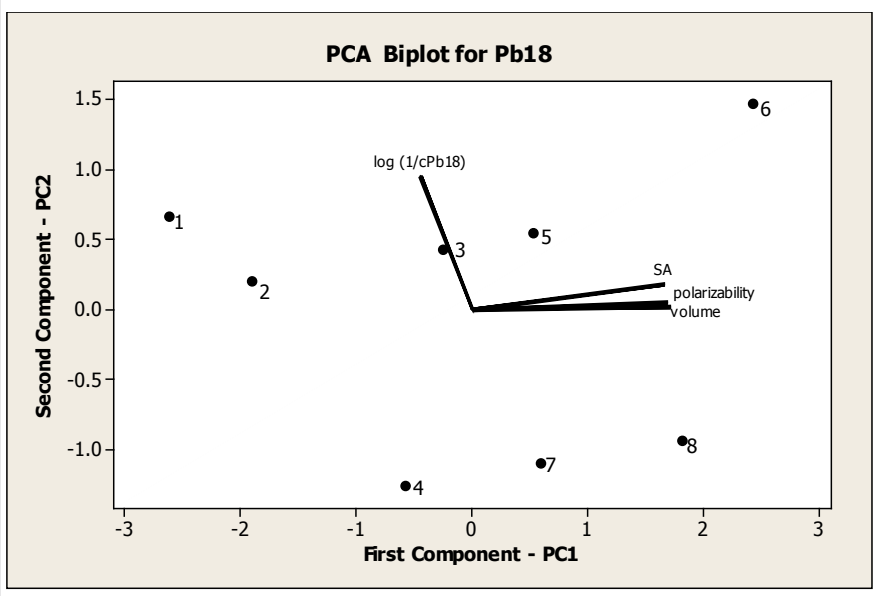

Figure 4: PCA technique showing the compounds separation as function of antifungal activity (Score plot) and the mainly descriptors (Biplot) for Pb18 fungus.

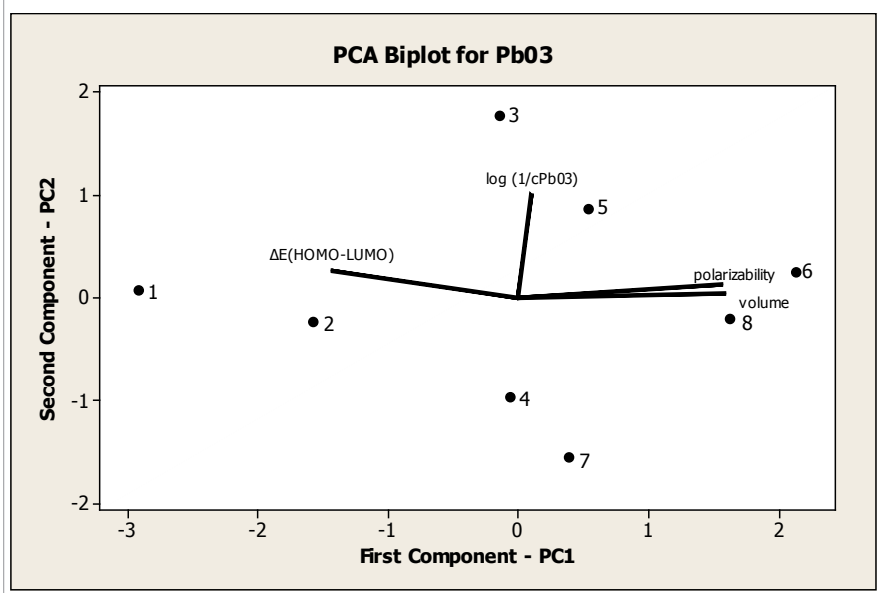

Figure 5: PCA technique showing the compounds separation as function of antifungal activity (Score plot) and the mainly descriptors (Biplot) for Pb03 fungus. 
Citation: Missau FC, Johann S, de Sá NP, Cisalpino PS, Rosa CA, et al. (2014) Phebalosin and its Structural Modifications are Active against the Pathogenic Fungal Causing Paracoccidioidomycosis. Med chem 4: 581-587. doi:10.4172/2161-0444.1000197

Paracoccidioides, with MIC values close to those found in present work, using RPMI medium, range $0.25-2 \mu \mathrm{g} / \mathrm{ml}$ and $300-75 \mu \mathrm{g} / \mathrm{ml}$ for amphotericin B and trimethoprim-sulfamethoxazole, respectively [25].

The chemometric results, derived from quantum chemistry calculations, revealed the same tendency observed from experimental data: structural properties are responsible for the antifungal activity. Polarizability, surface area and volume showed a good correlation with activity. In spite of all the observations, it's important to remark that the variation of energy between the frontier orbitals $\left(\Delta \mathrm{E}_{\text {номо-LUмо }}\right)$ is an important property related to activity, either.

Despite the chemometric analysis is not completely conclusive, PCA technique was able to separate the compounds as function of antifungal activity. In order to increase the antifungal activity, it can be suggested that structural modifications of phebalosin should have the following properties: greater values for polarizability, volume and the variation of energy between the frontier orbitals $\left(\Delta \mathrm{E}_{\text {номо-LUмо }}\right)$. It pointed to steric influence (volume), lipophilicity character (polaizability and volume) and compound stability during the interaction (electronic influence, $\Delta \mathrm{E}_{\text {номо-цUмо }}$ ) for the substituint alkyl groups.

In conclusion, phebalosin showed promised antifungal activity against isolates of $P$. brasiliensis tested. The structural modifications of phebalosin with different nucleophiles yielded seven compounds, four being new compounds $(8,4,5,6)$. Overall, these data open new possibilities for the potential use of phebalosin and its structural modifications as possible antifungal drugs against $P$. brasiliensis. However, new studies are necessary to characterize the mechanism of action of these compounds and produce more conclusive chemometric data.

\section{Acknowledgements}

This work was funded by Conselho Nacional de Desenvolvimento Científico Tecnológico (CNPq), Fundação do Amparo a Pesquisa do Estado de Minas Gerais (FAPEMIG) and the Coordenação de Aperfeiçoamento de Pessoal de Nível Superior (CAPES).

\section{References}

1. Sajora M, Santhi R, Annapoorani S (2012) Wound healing activity of flavonoid fraction of Cynodondactylon in Swiss albino mice. Int Res J Pharm 3: 230-231.

2. MacKay D, Miller AL (2003) Nutritional support for wound healing. See comment in PubMed Commons below Altern Med Rev 8: 359-377.

3. Guo S, Dipietro LA (2010) Factors affecting wound healing. See comment in PubMed Commons below J Dent Res 89: 219-229.

4. Tonnesen MG, Feng X, Clark RA (2000) Angiogenesis in wound healing. See comment in PubMed Commons below J Investig Dermatol Symp Proc 5: 40-46.

5. Edwards R, Harding KG (2004) Bacteria and wound healing. See comment in PubMed Commons below Curr Opin Infect Dis 17: 91-96.

6. Davis SC, Ricotti C, Cazzaniga A, Welsh E, Eaglstein WH, et al. (2008) Microscopic and physiologic evidence for biofilm-associated wound colonization in vivo. See comment in PubMed Commons below Wound Repair Regen 16: 23-29.

7. Sasidharan S, Nilawatyi R, Xavier R, Latha LY, Amala R (2010) Wound healing potential of Elaeis guineensis Jacq leaves in an infected albino rat model. See comment in PubMed Commons below Molecules 15: 3186-3199.

8. Okafo JC, Myrianthus arboreus P. Beauv PROTA 2 (2004) Vegetables/ Légumes PROTA, Wageningen Netherlands.
9. Burkill HM (1997) The useful plants of West Tropical Africa, 2nd ed., volume 2, Families E- I. Royal Botanic Gardens, Kew, Richmond, United Kingdom.

10. Agyare C, Asase A, Lechtenberg M, Niehues M, Deters A, et al. (2009) An ethnopharmacological survey and in vitro confirmation of ethnopharmacological use of medicinal plants used for wound healing in Bosomtwi-Atwima-Kwanwoma area, Ghana. See comment in PubMed Commons below J Ethnopharmacol 125: 393-403.

11. Mavar-Mangar H, Lejoly J, Quetin-Leclercq J, Schelzer GH (2007) Alchornea cordifolia (Schumach. \& Thonn.) Müll. Arg. PROTA, Wageningen, Netherlands.

12. Evans WC (2009) Trease and Evans' Pharmacognosy. 16th ed. Elsevier Health Sciences, United Kingdom.

13. Sofowora A (1993) Medicinal plants and traditional medicine in Africa, Spectrum Books, Ibadan.

14. Harborne JA (1988) Phytochemical methods: A guide to modern techniques of plant analysis. Plant Sciences 14: 302.

15. Agyare C, Koffuor GA, Boakye YD, Mensah KB (2013) Antimicrobial and anti-inflammatory properties of Funtumia elastica. See comment in PubMed Commons below Pharm Biol 51: 418-425.

16. Agyare C, Koffuor GA, Boamah VE, Adu F, Mensah KB, et al. (2012) Antimicrobial and Anti-Inflammatory Activities of Pterygota macrocarpa and Cola gigantea (Sterculiaceae). See comment in PubMed Commons below Evid Based Complement Alternat Med 2012: 902394.

17. Eloff JN (1998) A sensitive and quick microplate method to determine the minimal inhibitory concentration of plant extracts for bacteria. See comment in PubMed Commons below Planta Med 64: 711-713.

18. British Pharmacopoeia. Stationary Office, London, United Kingdom, 2007.

19. Ugboduma AO, Adu F, Agyare C, Annan K, Osei-Asante S (2013) Phytochemical screening and antimicrobial activity of Entandrophragma angolense. J Pharm Nutr Sci 3: 241-249.

20. Chizzola R, Michitsch H, Franz C (2008) Antioxidative properties of Thymus vulgaris leaves: comparison of different extracts and essential oil chemotypes. See comment in PubMed Commons below J Agric Food Chem 56: 6897-6904.

21. Ebi GC (2001) Antimicrobial activities of Alchornea cordifolia. See comment in PubMed Commons below Fitoterapia 72: 69-72.

22. Biapa PC, Agbor GA, Oben JE, Ngogang JY (2007) Phytochemical studies and antioxidant properties of four medicinal plants used in Cameroon. See comment in PubMed Commons below Afr J Tradit Complement Altern Med 4: 495-500.

23. Fabry W, Okemo PO, Ansorg R (1998) Antibacterial activity of East African medicinal plants. See comment in PubMed Commons below J Ethnopharmacol 60: 79-84.

24. Nayak BS (2006) Cecropia peltata L(Cecropiaceae) has wound-healing potential: a preclinical study in a Sprague Dawley rat model. See comment in PubMed Commons below Int J Low Extrem Wounds 5: 20-26.

25. Houghton PJ, Hylands PJ, Mensah AY, Hensel A, Deters AM (2005) In vitro tests and ethnopharmacological investigations: wound healing as an example. See comment in PubMed Commons below J Ethnopharmacol 100: 100-107. 